\title{
Drying Bacterial Biosaline Patterns Capable of Vital Reanimation upon Rehydration: Novel Hibernating Biomineralogical Life Formations
}

\author{
José María Gómez Gómez,,2 Jesús Medina,, David Hochberg,,3 Eva Mateo-Martí,1,3 \\ Jesús Martínez-Frías, ${ }^{1,4}$ and Fernando Rull ${ }^{1,3}$
}

\begin{abstract}
Water is the fundamental molecule for life on Earth. Thus, the search for hibernating life-forms in waterless environments is an important research topic for astrobiology. To date, however, the organizational patterns containing microbial life in extremely dry places, such as the deserts of Earth, the Dry Valleys of Antarctica, or Mars analog regolith, have been poorly characterized. Here, we report on the formation of bacterial biosaline self-organized drying patterns formed over plastic surfaces. These emerge during the evaporation of sessile droplets of aqueous $\mathrm{NaCl}$ salt $0.15 \mathrm{M}$ solutions containing Escherichia coli cells. In the present study, scanning electron microscopy (SEM) and energy dispersive X-ray spectrometry (EDS) analyses indicated that the bacterial cells and the $\mathrm{NaCl}$ in these biosaline formations are organized in a two-layered characteristic 3-D architectural morphology. A thin filmlike top layer formed by $\mathrm{NaCl}$ conjugated to, and intermingled with, "mineralized" bacterial cells covers a bottom layer constructed by the bulk of the nonmineralized bacterial cells; both layers have the same morphological pattern. In addition, optical microscopic time-lapsed movies show that the formation of these patterns is a kinetically fast process that requires the coupled interaction between the salt and the bacterial cells. Apparently, this mutual interaction drives the generative process of selfassembly that underlies the drying pattern formation. Most notably, the bacterial cells inside these drying selfassembled patterns enter into a quiescent suspended anhydrobiotic state resistant to complete desiccation and capable of vital reanimation upon rehydration. We propose that these $E$. coli biosaline drying patterns represent an excellent experimental model for understanding different aspects of anhydrobiosis phenomena in bacteria as well as for revealing the mechanisms of bacterially induced biomineralization, both highly relevant topics for the search of life in extraterrestrial locations. Key Words: Escherichia coli-Self-organized bacterial drying pattern formation-Hibernating life-Biosaline biomineralogical life formations-Anhydrobiosis-Biologically induced biomineralization (BIM). Astrobiology 14, 589-602.
\end{abstract}

\section{Introduction}

W ATER IS A MOLECULE essential for life (De Duve, 1996; McKay, 2004). Hence, one of the most important environmental stresses life faces in nature is desiccation (Grant, 2004). Many sites selected for current and future astrobiological research are dry, arid locales that range from the extremely dry Atacama Desert and Dry Valleys of Antarctica to the surface of Mars (Carr, 2006; Vítek et al., 2012; Westall et al., 2013; Ziolkowski et al., 2013). Hence, the study of resistance mechanisms that might allow for the survival of anhydrobiotic organisms in desiccated conditions, as well as the identification of new anhydrobiotic organisms on Earth, is an important aspect of astrobiological research.

Desiccation refers to the extreme dehydration of cells when the hydration shell of molecules is gradually lost (Billi and Potts, 2000). It is well known that the removal of water through air-induced drying damages membranes, proteins, and nucleic acids and is lethal to the majority of organisms (Potts, 1994). Nevertheless, anhydrobiotic organisms such

\footnotetext{
${ }^{1}$ Laboratory of BioMineralogy and Astrobiological Research (LBMARS), Unidad Asociada UVA-CSIC, Edificio INDITI, Boecillo, Valladolid, Spain.

${ }^{2}$ OAS-BioAstronomy Group, Observatorio Astronómico de Segurilla (OAS), Segurilla, Toledo, Spain.

${ }^{3}$ Centro de Astrobiología (CSIC-INTA), Torrejón de Ardoz, Madrid, Spain.

${ }^{4}$ Instituto de Geociencias, IGEO (CSIC-UCM), Facultad de Ciencias Geológicas, Madrid, Spain.
} 
as certain vegetative cells of bacteria, cyanobacteria, and higher organisms, for example, tardigrades, can survive extreme desiccation (Potts, 1994; Billi and Potts, 2002; Jönsson, 2007). Anhydrobiosis refers to the state in which an organism stops its vital functions temporarily due to partial or total desiccation (Potts, 1994). This quiescent state is characterized by an extreme reduction of measurable metabolism (Billi and Potts, 2002). Desiccated cells do not grow, and the time during which they remain dried may represent the greater part of their life span. When rehydrated, anhydrobiotes revive and resume active metabolism. Interestingly, the maximal longevity of microorganisms in a metabolically inactive, desiccated state is currently unknown (Kennedy et al., 1994). Numerous cellular mechanisms responsible for enhanced desiccation resistance in bacteria have been identified, including de novo trehalose synthesis, production of extracellular polymeric substances (EPS), and uptake of exogenous glycine betaine (Billi and Potts, 2002).

Related to the previous issue, desiccation has other notable consequences as well for both abiotic and biotic systems. For instance, it is well documented that the evaporation of water drives the formation of the different self-organized patterns that emerge in drying conditions, such as in small droplets containing different kinds of solutes (Deegan, 2000). Drying dissipative patterns have been studied for many kinds of suspensions and solutions of colloidal particles, linear-type synthetic and biopolyelectrolytes, water-soluble neutral polymers, ionic and non-ionic detergents, gels, colloidal polymer-complex, and dyes (Kaya et al., 2010; Okubo, 2011). In addition, drying patterns have been observed with biological macromolecules, for example, salt solutions of DNA (Jing et al., 1998; Okubo et al., 2010) and proteins (Shiba et al., 2003; Chen and Mohamed, 2010; Ma et al., 2013) and human fluids (e.g., blood, Brutin et al., 2011). However, despite the fact that bacteria are the most abundant cellular organisms that thrive on Earth (Staley et al., 2007) and numerous fundamental biological issues have been decoded and unraveled when using these organisms as biological models, the study of drying patterns and bacteria has not been previously reported.

During the motility study of Escherichia coli cells inside a simple microcosmos, a droplet of $\mathrm{NaCl}$ physiological saline solution $(9 \mathrm{mg} / \mathrm{mL}, 0.15 \mathrm{M})$, we found unexpectedly that bacterial cells underwent self-assembly in conjunction with the $\mathrm{NaCl}$ (driven by water evaporation) that produced complex biosaline drying patterns on plastic surfaces. In this way, the evaporating water generates regular patterns with a good reproducibility for the several common wild-type E. coli K-12 laboratory and mutant strains assayed in this study (see Materials and Methods).

In this work, we characterize the macroscopic and microscopic structural organization of these bacterial drying biosaline formations and report the reversible vitality exhibited by the bacterial cells that form these patterns. Finally, we discuss the significance of these findings from an astrobiological perspective, which could be important for the search for hibernating extraterrestrial resistant organisms. Additionally, we suggest that these patterns might serve as biomarkers detectable by imaging systems during planetary exploration.

\section{Materials and Methods}

\subsection{Escherichia coli strains, media, and growth conditions}

The Escherichia coli MG1655 K-12 (Blattner et al., 1997; Dragosits et al., 2013), MG1655 str $^{\mathrm{R}}$ (Gauger et al., 2007), W3110 (Khankal et al., 2009), and NMHK8 (BW25113 sdiA::cat) (Høyland-Kroghsbo et al., 2013), NM525 and GSO553 (NM525 AfhDC::kan) (Thomason et al., 2012) strains were used in this work. The media used was LuriaBertani (LB) medium (Gómez-Gómez et al., 1996): 1.0\% (10 g/L), Difco Bacto-tryptone (Lot $\left.\mathrm{n}^{\circ} 3113075\right), 0.5 \%$ (5 g/L), Difco yeast extract (Lot $\left.n^{\circ} 6257032\right)$ and $0.5 \%(5 \mathrm{gr} / \mathrm{L} \mathrm{NaCl}$ Merck, Lot $\left.\mathrm{n}^{\circ} 1064041000\right)$. The LB medium was jellified with Agar Bacteriológico Europeo (ABE, Lot n¹5100184) at the concentration indicated. The physiological saline solution of $\mathrm{NaCl}(9 \mathrm{mg} / \mathrm{mL}, 0.15 \mathrm{M})$ employed was commercially made and distributed by the Fresenius Kabi España S.A. company under the name Cloruro de Sodio Meinsol. Similar results were obtained with a solution of $\mathrm{NaCl}$ (obtained from VWR Chemicals) prepared with Milli- $Q$ water.

\subsection{Experimental setup to study biosaline bacterial drying patterns}

The experimental protocol for droplet evaporation was carried out with the following procedure: the different E. coli K-12 strains used in this work were grown in Petri dishes prepared with LB ABE agar $1.5 \%$ (15 g/L). The cells obtained from a colony grown from these plates were inoculated with a toothpick at the center of an $8.5 \mathrm{~cm}$ Petri dish containing $30 \mathrm{~mL}$ of liquid LB medium, harnessed with $0.6 \%(6 \mathrm{~g} / \mathrm{L})$ ABE agar. The plates were sealed with Parafilm to prevent loss of water and cultivated at $37^{\circ} \mathrm{C}$. The plastic Petri dishes made of polystyrene are manufactured by the Sterilin company (http://www.sterilin.co.uk).

The in vitro setup was established as follows: approximately $5 \times 10^{9}$ bacterial cells from an E. coli K-12 strain macrocolony biofilm grown at $37^{\circ} \mathrm{C}$ during 14 days, similar to the one shown in Fig. 1A (the colonial pattern-morphotype exhibited by these colonies was described by Gómez-Gómez and Amils, 2014), were carefully removed from the agar plate and suspended into a droplet $(200 \mu \mathrm{L})$ of physiological salt $\mathrm{NaCl}$ solution $(9 \mathrm{mg} / \mathrm{mL}, 0.15 \mathrm{M})$ that was placed on the plastic surface of a Petri dish. This simple experimental microcosmos simulates environmental situations where the continuous supply of nutrient inflow is insufficient to support active bacterial growth, and the bacterial behavior observed necessarily might depend exclusively on bacterial motility. The evolution in appearance and behavior of this bacterial community inside the droplet at room temperature $\left(<25^{\circ} \mathrm{C}\right)$ was observed directly under the objective of an Ultralyt ULNM-90-10000 microscope, which was coupled to a digital camera, over that period of time sufficient for complete droplet desiccation. The plates were photographed with reflected light with a Kodak Easy Share Z710 digital camera.

Figure images were prepared with the Microsoft Photo Editor program and Microsoft PowerPoint software.

\subsection{Cell viability assay}

Cells extracted from the drying biosaline droplets were resuspended in $200 \mu \mathrm{L}$ of fresh $\mathrm{LB}$ medium, and $100 \mu \mathrm{L}$ of 

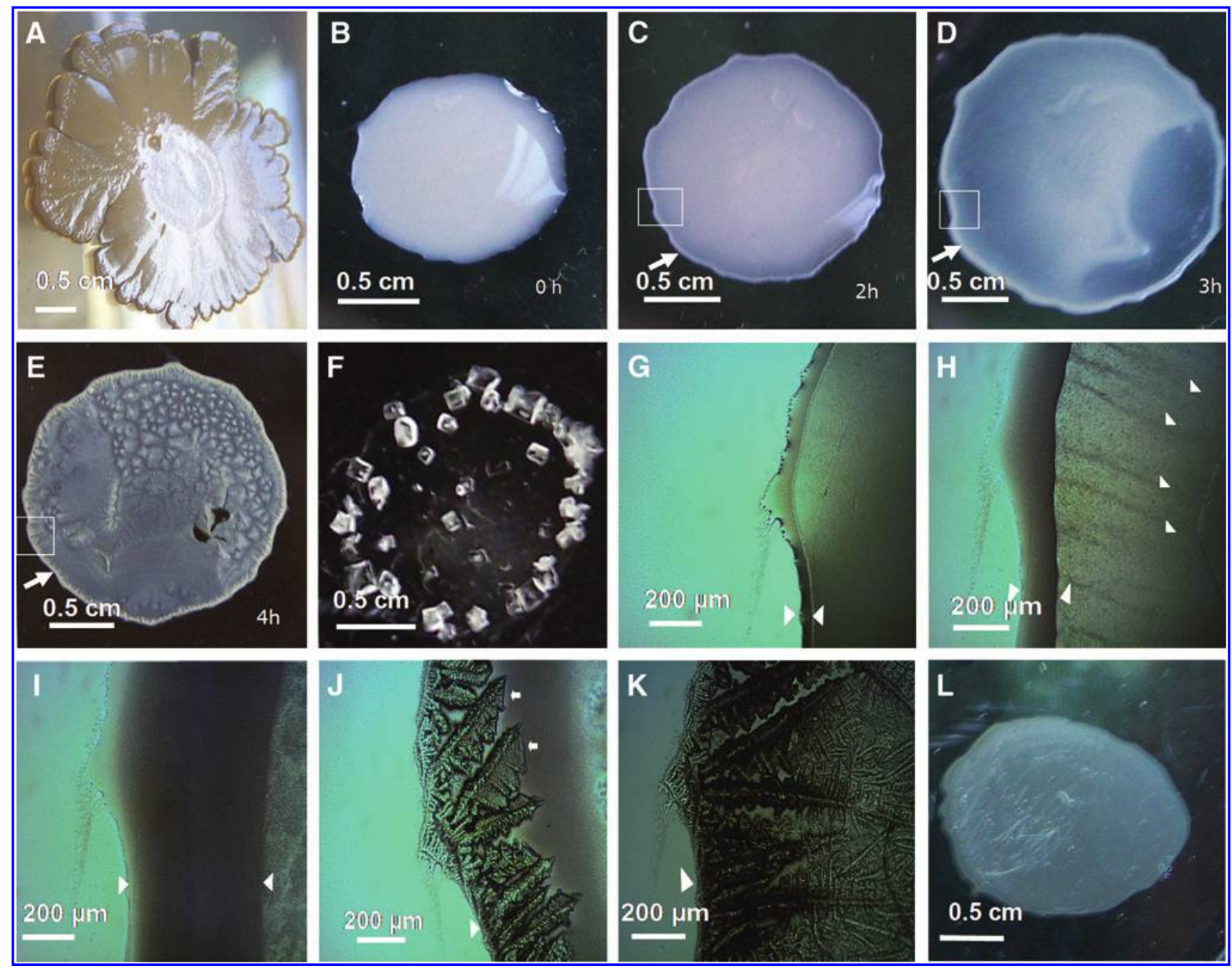

FIG. 1. Macroscopic and optical microscopic study of E. coli saline drying patterns in aqueous solution of $\mathrm{NaCl} 0.15 \mathrm{M}$ on plastic Petri dish surfaces. (A-E) A typical experiment where the drying biosaline patterns are observed. (A) A typical E. coli $\mathrm{K}-12 \operatorname{str}^{\mathrm{R}}$ strain macrocolony 14 -day-old biofilm developed at $37^{\circ} \mathrm{C}$ over a semisolid $0.6 \%$ ABE agar surface used as biological material in this study. (B-D) Optical microscope images showing different snapshots of the change over time of the external appearance of a drying saline $(\mathrm{NaCl} 0.15 \mathrm{M})$ droplet loaded with $E$. coli cells from a macrocolony biofilm. (E) Typical macroscopic aspect of a complete $\mathrm{NaCl}$ saline E. coli dried biofilm. The images were taken at different moments of time indicated, after the cell inoculation into a droplet. (F) Dried droplet that contained only physiological saline $\mathrm{NaCl}$ solution. The arrows in (C-E) indicate the biofilm edge. (G-K) Different microscopic snapshots taken of biofilm's edge boxed in images (CE). (G) Seven minutes, (H) $16 \mathrm{~min}$, (I) $170 \mathrm{~min}$, (J) $175 \mathrm{~min}$, (K) $200 \mathrm{~min}$ after cells were added to droplet. The small arrowheads in $(\mathrm{H})$ show the position of the bacterial swarming streams forming characteristic stripes. In (G-I) the two opposing arrowheads show the thickness of the biofilm edge; in $(\mathrm{J}-\mathrm{K})$ the arrowhead indicates the biofilm edge. $(\mathrm{J})$ The arrows indicate the advancing edge of the biosaline pattern formation. (K) Microscopic aspect of the bacterial border completely formed by drying biosaline patterns. (L) Control droplet of Milli- $Q$ water loaded with E. coli cells without added NaCl. (Color images available online at www.liebertonline.com/ast)

this was used to prepare serial dilutions in LB medium. One hundred microliters obtained from the appropriate dilutions was spread in Petri dishes prepared with $30 \mathrm{~mL}$ of LB medium harnessed with $1.5 \% \mathrm{ABE}$ agar $(15 \mathrm{~g} / \mathrm{L})$. The plates were then incubated overnight at $37^{\circ} \mathrm{C}$, after which the colonies were counted. During each day, as shown in Fig. 6P, the viability of three independent drying biosaline patterns was measured.

\subsection{Scanning electron microscopy and energy dispersive $X$-ray spectrometry}

The scanning electron microscopy (SEM) and energy dispersive X-ray spectrometry (EDS) analyses were per- formed with a FEI-Quanta 200FEG electron microscope that used an acceleration voltage of $5.00 \mathrm{keV}$. The scanning electron microscope images were obtained with scanning modes by the detection of secondary electrons and backscattered electrons.

\section{Results}

\subsection{Motility behavior of $\mathrm{E}$. coli cells inside the saline} droplet $(0.15 \mathrm{M} \mathrm{NaCl})$ prior to formation of the drying pattern

To inhabit and maintain a population in soil, E. coli must have the capacity to resist soil environmental stresses, one 
of which is the desiccation stress associated with natural soil wetting-drying cycles (Zhang and Yan, 2012). To learn how $E$. coli cells respond to the exposure of water evaporation under in vitro controlled conditions, the E. coli cells obtained from the colonies grown in semisolid LB agar (Fig. 1A) were resuspended in small droplets of a $\mathrm{NaCl}$ $0.15 \mathrm{M}$ solution. Monitoring the evaporating droplet under the microscope revealed that several minutes $(\sim 5-7 \mathrm{~min})$ after their inoculation, the bacterial cells rapidly began an active accumulation at the "edge" of the droplet (Fig. 1B) that formed the exterior boundary along the perimeter of the droplet (Fig. 1C, 1D). This edge increased its thickness with time through a massive bacterial accretion driven apparently by a process of the cell-to-cell aggregation (Fig. $1 \mathrm{G}-1 \mathrm{I})$. Furthermore, we observed the generation of the fine bacterial "streams" forming stripes aligned in the direction of the edge of the biofilm inside the droplet (Fig. $1 \mathrm{H}$ and see Movie S1 in the Supplementary Material, available online at www.liebertonline.com/ast). To the best of our knowledge, this kind of apparently collective movement of $E$. coli over plastic surfaces has not been previously reported.

In this respect, it is well known that swarming is a form of collective motility. Thus, during swarming motility, the E. coli "swarmer" cells carry out a collective movement (i.e., this kind of bacterial migration is a social rather than individual trait, Copeland and Weibel, 2009) over solid surfaces (generally over semisolid agar surfaces with nutrients supporting the bacterial growth and swarming movement) and participate in the formation of coordinated patterns of group activity that emerge as a consequence of the collective motion, which is something akin to the behavior exhibited by a swarm of bees (Harshey, 1994). The E. coli swarming behavior is driven by flagella and requires metabolically produced energy, which is necessary to power the flagellar rotatory motors that control the rotation of the flagella that propel the bacteria in this active movement (Gómez-Gómez et al., 2007; Kearns, 2010).

To determine whether this collective bacterial movement observed in drying, evaporating droplets is an active process that requires flagella, we examined the behavior of $2.5 \times 10^{9}$ E. coli NM525 $\triangle$ fhDC: :kan cells loaded in a $\mathrm{NaCl} 0.15 \mathrm{M}$ droplet (this $E$. coli strain lacks the flagellar master regulator FlhDC and is thereby unable to produce flagella, Thomason et al., 2012) in comparison to its wild-type NM525 motile strain under the microscope. The swarming-like stream patterns generated by the collective motion of the E. coli wild-type motile strain were not observed in this mutant strain that lacks the flagella (data not shown), which indicates that flagella are required for the emergence of stream patterns of bacterial collective movement within the $\mathrm{NaCl}$ evaporating droplet. These results appear to rule out the hypothesis that forces of nonbiological origin generate "patterns of flow" in the fluid (e.g., convective streams) of the droplet that drag the bacteria and mimic the illusion of an active bacterial collective motion. Here, we suggest the possibility that the emergence of this collective streaming bacterial movement, under these crowded bacterial conditions in drying $\mathrm{NaCl}$ droplets, could be interpreted as a kind of swarming-like collective behavior. It is clear, however, that additional future experiments will need to be carried out to clarify this hypothetical supposition.
Intriguingly, for the E. coli NM525 $\triangle$ flhDC::kan mutant that is defective in the production of flagella, a residual bacterial movement was observed that generated an edge in the droplet Interestingly, E. coli movement on a surface mediated by type 1 pili has been recently described (Kurihara et al., 2011). These results along with our findings suggest the possibility that several active motility modes (flagellar and nonflagellar dependent requiring energy) could be acting in evaporating droplets. However, the possibility that passive movement (i.e., random Brownian motion) could occur in conjunction with active bacteriaproduced movement to generate, as a final net outcome, the global bacterial collective movement observed in evaporating droplets cannot be completely ruled out. Future experiments will clarify the nature of the phenomenon of collective bacterial movement in drying saline droplets.

\subsection{Complex bacterial biosaline drying pattern formation on plastic surfaces}

The evolution of bacterial movement inside the $\mathrm{NaCl}$ saline droplet was monitored during approximately $4 \mathrm{~h}$ at room temperature. After this elapsed time, the water evaporation triggered a rapid process of salt crystallization. This process was initiated suddenly from the edge of the biofilm (Fig. 1J) and advanced along the periphery of the droplet to completely cover the bacterial edge (Fig. 1K). The ongoing water evaporation generates a centripetal drying pattern formation process toward the center of the biofilm (Fig. 1J and see Movie S2 in the Supplementary Material) in a manner such that, after a few minutes, a complete biosaline pattern of the border is achieved for the whole of the droplet (Fig. 1E). It was also observed that this process apparently dragged the self-assembly of the $E$. coli bacterial cells into complex drying patterns (Fig. 1J). In addition, different foci of pattern formation are observed in the interior of this class of biofilms and show, in some cases, confluence in their borders (Fig. 1E and Fig. 2E, 2F). That is, the bacterial cells underwent a process of crowding and aggregation that was salt-induced and driven by water evaporation, leading to the formation of a "dried saltentrapped bacterial tapestry" composed of distinct " $E$. coli biosaline drying patterns." To our knowledge, this kind of bacterial biosaline self-organized pattern has not been reported before. Here, in the context of this work, self-organization means that the acquisition of order and structure during the pattern formation process occurs through interactions internal to the system, without intervention by external directing influences. In other words, the self-organized pattern is an emergent property of the system, rather than a property imposed on the system by an external ordering influence (Ball, 1999; Camazine et al., 2001).

On the other hand, in the Petri dish control plates containing just the $\mathrm{NaCl}$ salt but no bacteria, only the faceted, blocky shapes of typical $\mathrm{NaCl}$ abiotic crystals were observed (lattice constant: $5.65 \AA$ ) (Fig. 1F and Fig. 2L). In addition, in the absence of $\mathrm{NaCl}$, no patterns of this kind are generated by the bacterial cells alone (Fig. 1L). Therefore, both bacterial cells and $\mathrm{NaCl}$ are necessary for these biosaline drying patterns to emerge.

The appearance of microscopic drying patterns changes drastically depending on the location in the dried film (Fig. 1E); however, a number of different patterns can be 


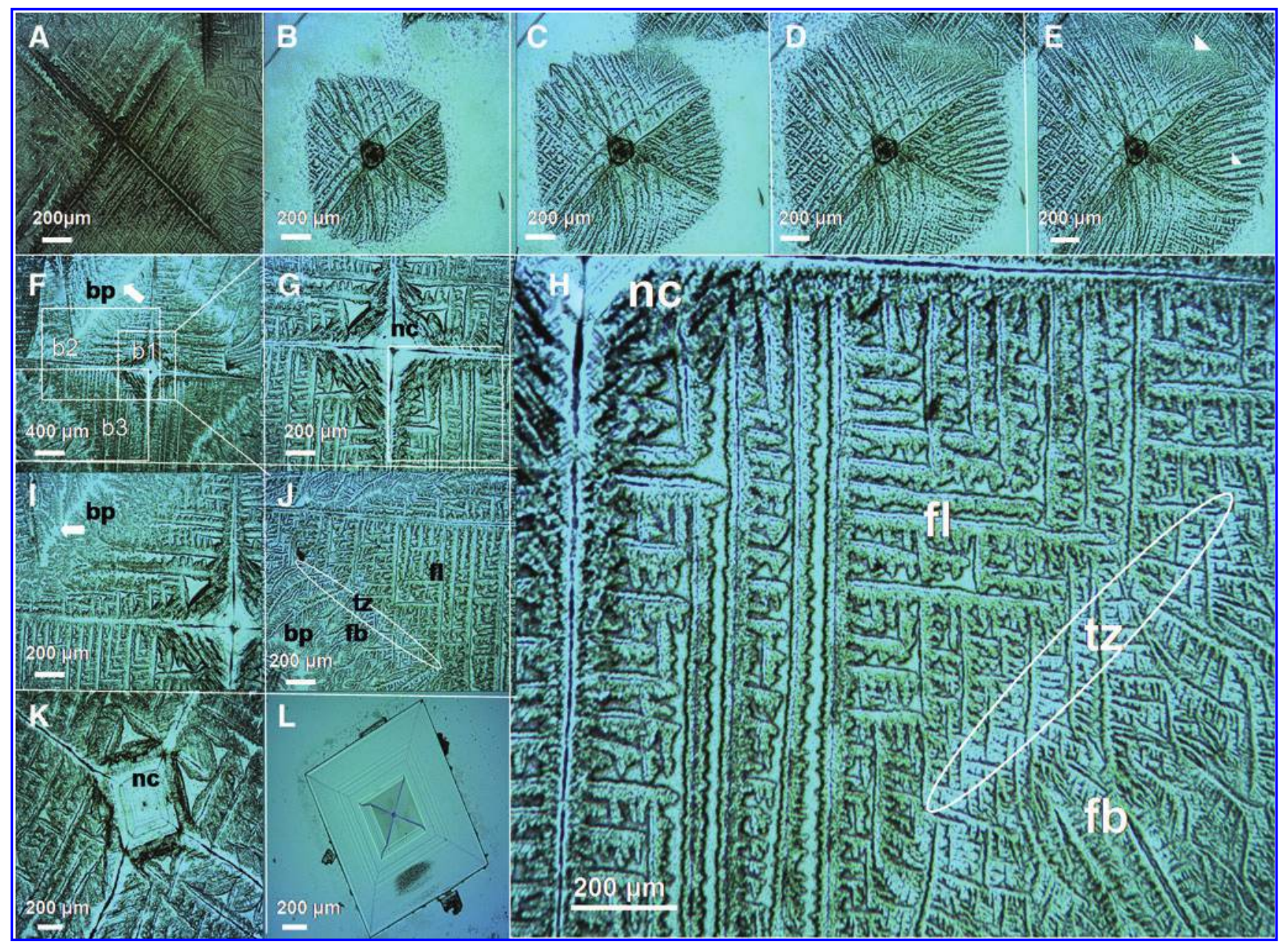

FIG. 2. Typical microscopic biosaline drying patterns observed in dried E. coli biofilms and typical abiotic inorganic $\mathrm{NaCl}$ crystal. (A) Representative drying pattern exhibiting cross-symmetry observed in a typical biosaline E. coli tapestry inside a dried droplet as shown in the box of Fig. 1E. (B-E) Snapshots showing the assembly of E. coli cells $+\mathrm{NaCl}$ in a coupled formative process to generate a complex biosaline pattern exhibiting cross-symmetrical morphology; the time lapsed between the capture of image (B) and (E) was $40 \mathrm{~s}$. (F) Typical cross-symmetrical drying biosaline pattern showing a typical nucleating central $\mathrm{NaCl}$ crystal generative of the fractal-like salt-bacteria $+\mathrm{NaCl}$ assemblage pattern. (G) Enlargement of box 1 (b1) in $(F)$. (H) Enlargement of the box in $(G)$, in this image, indicates the different zones that form the drying pattern. The oval white lines indicate the transitional zone (tz) among different pattern zones. (I) Enlargement of box 2 (b2) shown in (F). (J) Enlargement of box 3 (b3) in (F); the oval white lines indicate the transitional zone. The arrowhead in (E) indicates a confluence zone among patterns; by contrast, the arrows in (F) and (I) indicate an avoidance zone. (K-L) Comparison between $(\mathrm{K})$ a nucleating $\mathrm{NaCl}$ crystal + bacteria drying pattern and (L) a typical microscopic image of a cubic $\mathrm{NaCl}$ crystal observed in the control plate (Fig. 1F). Abbreviations: nc, nuclear core; fl, fractal-like; fb, fern-leaf bushy zone; $\mathrm{bp}$, boundary of the pattern; tz, transitional zone. (Color images available online at www.liebertonline.com/ast)

observed. We briefly describe the most common one, a pattern that exhibits fractal-like growth and exhibits a characteristic cross-symmetrical organization (Fig $2 \mathrm{~A}-2 \mathrm{~K}$ ). In the center of this pattern there is a typical morphology of a $\mathrm{NaCl}$ crystal (Fig. 2A, 2B, 2F-2I, and 2K), indicating that the cross-symmetry exhibited by this pattern is inherited from the cubic habit of an initial nucleating founder (Adam) $\mathrm{NaCl}$ crystal. Furthermore, the patterns have a rich internal morphological structure that changes with the distance from the nucleating center of the pattern. Thus, in the presence of bacterial cells, an Adam $\mathrm{NaCl}$ crystal develops dendritic structures that arise initially from the corner of the cubic formation to create a characteristic fractal-like pattern (Fig. $2 \mathrm{H})$. A transition zone is observed where the pattern changes from fractal to bushy fern-leaf morphology. Therefore, the different zones can be identified in this complex pattern and are denoted as follows: the nuclear core (nc), fractal-like zone (fl), and a fern-leaf bushy zone (fb), which terminates in the boundary of the pattern (bp) that forms in the confluence zone with other similar patterns (Fig. 2F and 2I, 2J). In addition, in this kind of pattern, there are zones where a complete confluence among the dendritic structures can be observed (Fig. 2E), as well as zones where this contact does not occur (Fig. 2F and 2I, 2J).

Interestingly, the drying biosaline patterns generated by the E. coli NM525 $\triangle f l h D C:: k a n$ strain are similar to those observed in wild-type strains (for instance, cross-symmetrical patterns similar to those shown in Figs. 2 and 3 are observed 


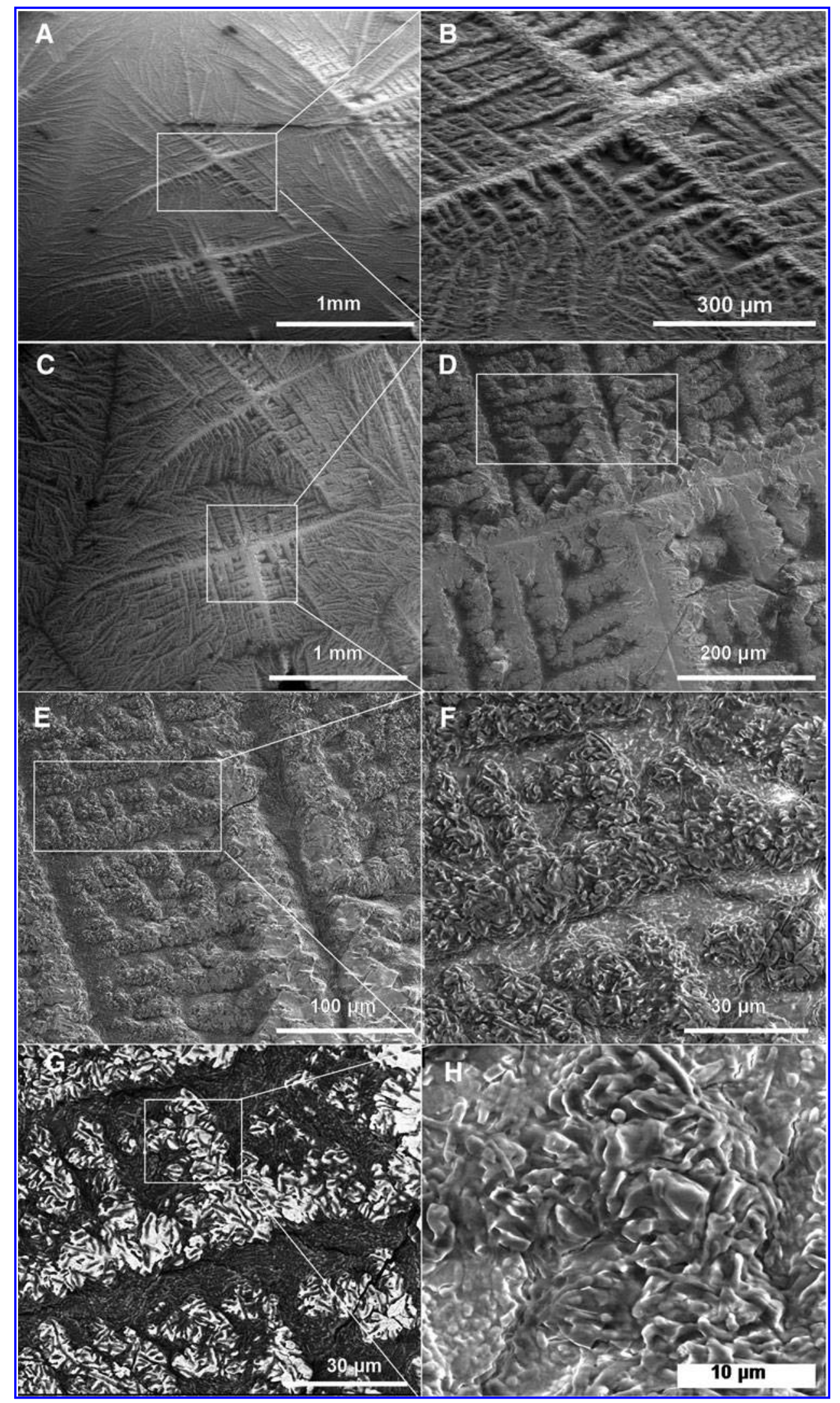

FIG. 3. Scanning electron microscope images of a typical nucleating core exhibiting a cross-symmetry fractal-like E. coli biosaline drying pattern. (A-B) Close-up view of a biosaline E. coli K-12 MG1655 strain drying pattern showing cross-symmetry fractal-like morphology. (C-H) Close-up view at higher magnifications of a fractal-like drying biosaline formation. (E) Enlargement of the box region in $(\mathrm{D})$. $(\mathrm{F}-\mathrm{G})$ Enlargement of the box region in $(\mathrm{E})$. $(\mathrm{H})$ Intermingled formations of $\mathrm{NaCl}+\mathrm{bacterial}$ cells are clearly visualized at this magnification. Secondary electrons were used to capture images (A, B, C, D, E, F, H), whereas image $(\mathrm{G})$ was obtained with backscattered electrons. 
in drying droplets of this E. coli strain; data not shown), indicating that during the process of biosaline drying pattern formation per se, flagella and flagella-driven motility are not factors involved directly in its formation.

The dynamics of the $\mathrm{NaCl}+$ bacteria pattern formation process was studied with time-lapsed video microscopy. The movies obtained during the droplet drying process (see Movies S2 and S3 in the Supplementary Material) demonstrate that the biosaline drying pattern formation is a kinetically fast process; typical snapshots extracted from these videos are shown in Fig. $1 \mathrm{~J}$ and $1 \mathrm{~K}$ and Fig. $2 \mathrm{~B}-2 \mathrm{E}$. The time-lapse Supplementary Movie S3 shows the formation of a typical biosaline pattern that exhibits cross-symmetrical geometry. Thus, given depictions as seen in these movies, we suggest that the pattern formation is a coupled process that involves the interaction of the bacterial cells and the $\mathrm{NaCl}$ salt, which leads to a simultaneous self-assembly of both biotic and abiotic components in an integrated biosaline self-organized drying structure.

Taken together, these results suggest that, although the bacteria apparently do not disrupt the initial $\mathrm{NaCl}$ nucleation process to form a primary $\mathrm{NaCl}$ crystal, they have the capacity to interfere with the "normal" abiotic inorganic formation of the $\mathrm{NaCl}$ crystal by modulating the subsequent growth and development of the $\mathrm{NaCl}$ crystal pattern that develops into a complex "organic crystal habit" (Ball, 1999).

\subsection{Scanning electron microscopy studies and energy dispersive $X$-ray spectrometry analyses of the biosaline drying patterns}

To better understand the microscopic architectural organization of the $E$. coli biosaline drying patterns, we studied them with SEM and EDS analysis. The scanning electron microscope images of the biosaline drying pattern observed in several E. coli strains-MG1655 (Fig. 3), NMHK8 and W3110 (Figs. 4 and 5)-indicate that the biosaline patterns have a complex 3-D architecture such that the $\mathrm{NaCl}$ and the bacterial cells share the same morphological pattern and possess a characteristic organizational mode. Indeed, the $\mathrm{NaCl}$ as determined by EDS analysis (Fig. 5G) is conjugate to, and intermingled with, the "mineralized" bacterial cells (Fig. 5F); thus a thin filmlike layer that constitutes the biomineralogical material is formed (Fig. 5G, 5H). Remarkably, as shown in Fig. 3H, the $\mathrm{NaCl}+$ bacteria interaction is extremely complex in the fractal line zone of the drying patterns, forming structures without a clear distinction between both components. Beneath this thin filmlike biomineralogical layer is the bulk of the drying pattern, which is constructed completely by bacterial cells (Fig. 4C).

Taking all these results into account, it is tempting to suggest that the $\mathrm{NaCl}$ can apparently be conjugated with bacterial cells growing its "organic habit" along the "scaffold" provided by the bacterial cells that self-assemble into a specific integrated bacteria $+\mathrm{NaCl}$ salt pattern. That is, the bacteria participate passively during the formation of the biosaline drying patterns and apparently provide a scaffold where the $\mathrm{NaCl}$ deposition and conjugation are carried out. In addition, these observations suggest that the bacteria as a whole have the ability to modulate crystal growth but also that the $\mathrm{NaCl}$ modulates reciprocally the formation of the bacterial pattern.

Thus, although the drying pattern formation requires both the bacterial and salt components, we cannot confirm with the available data that the bacteria carry out an active sensu stricto role, that is, whether metabolic energy is used per se by the bacterial cells specifically during the process of construction of the drying biosaline patterns, for instance, to generate movement of the $\mathrm{Na}^{+}$and $\mathrm{Cl}^{-}$ions. Future experiments will be designed and carried out to clarify this important point.

\subsection{Escherichia coli cells that self-organized into biosaline drying patterns display vital reversibility}

The next key hypothesis to be tested was whether the $E$. coli cells that enter into this self-assembled biosaline pattern in a "quiescent" state remain viable, that is, if they demonstrate the capacity to return to an active animated state (reanimation) after water is supplied to these saltentrapped biofilms. In other words, do the E. coli bacterial cells enter into an anhydrobiotic state or do they not when they form these drying patterns? To test this hypothesis, a 7day-old biosaline-dried bacterial biosaline biofilm (shown in Fig. 1E) was rinsed with a drop of fresh saline solution (Fig. 6A). Immediately after the drop was added (Fig. 6B), the bacterial biosaline patterns began to disassemble in a sequential and orderly fashion, releasing in this way the bacterial cells to the aqueous phase (Fig. 6F-6J). However, a remainder of tightly associated cells forming residual morphological patterns was still observed (data not shown). Then, surprisingly, both the cells that were liberated from the biosaline pattern as well as those that were liberated by mechanical disruption from these residual patterns were able to recover rapidly their "collective" activity of movement (see Movie S4 in the Supplementary Material), generating the characteristic edge of the droplet (Fig. 6K-6M and see Movies S5 and S6 in the Supplementary Material). Furthermore, as would be expected with water evaporation, the bacteria inside the biofilm again underwent (Fig. 6N, 6O) another cycle of the drying pattern formation, generating architectural patterns similar to those observed in the original foundational biosaline-drying biofilm; thus the process started all over again near the biofilm edge. The data indicate the likelihood that bacteria resist dissection when forming these drying patterns.

To confirm this suggestion, the viability of $E$. coli MG1655 strain cells in biosaline droplets kept at room temperature for 7 days was measured as explained in the Materials and Methods. As shown in Fig. 6P, a loss of viability (a reduction in viable cell counts) was observed between Day 1 and Day 2, but after this the viability remained stable with no additional decrease. Together, these results indicate that the bulk of bacterial cells that form a biosaline drying pattern withstand desiccation at least for 7 days after the formation of the drying pattern, and they are able to return to life (vital functions restored) after this elapsed time upon rehydration. Additionally, this experiment suggests that the collective bacterial movement observed under the microscope, when the water is supplied to the drying droplet, is likely a phenotypical manifestation of this cellular vitality. 


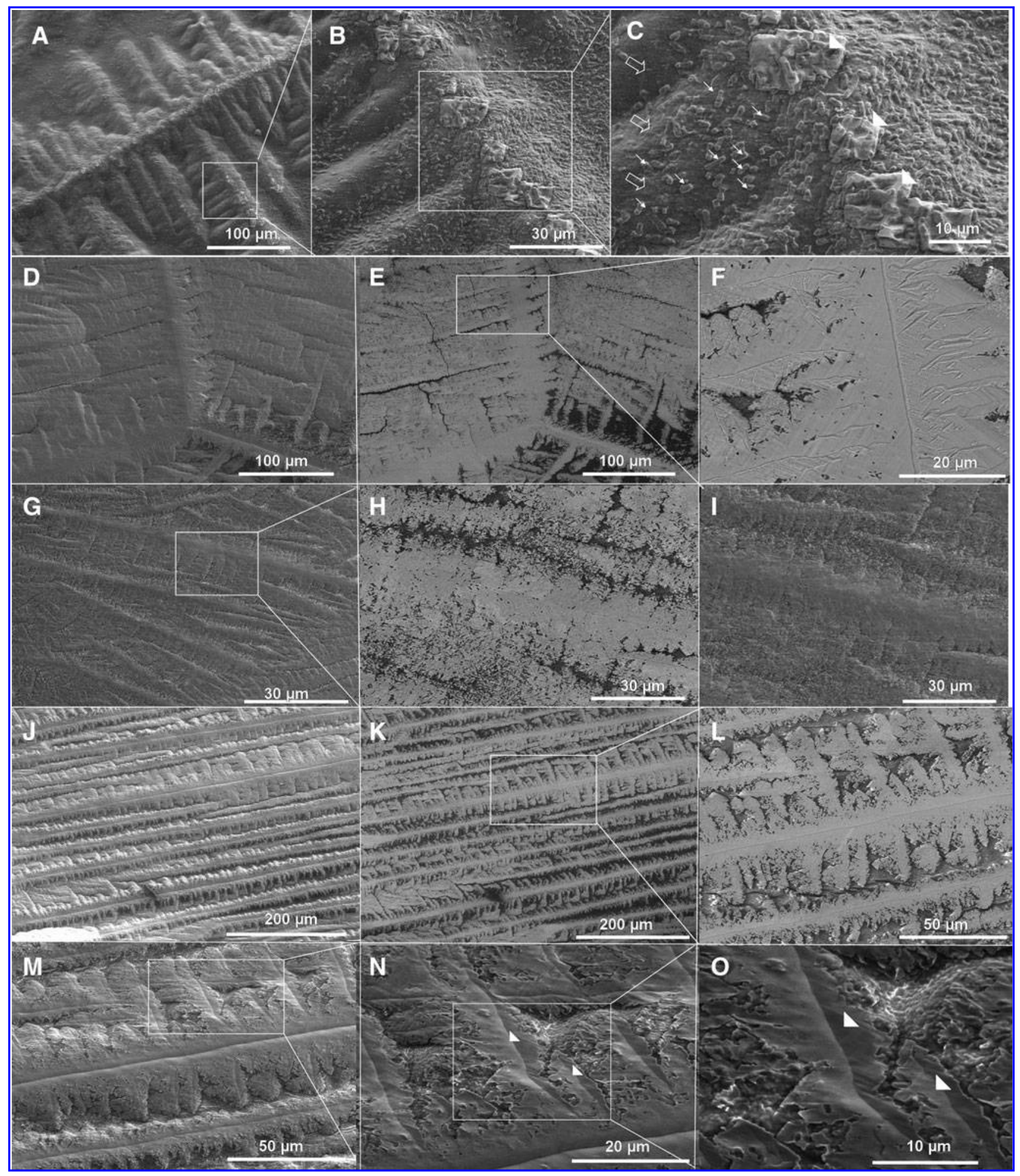

FIG. 4. Scanning electron microscope images of a typical drying E. coli bacterial-salt fern-leaf pattern. (A-C) A dried biosaline biofilm of $E$. coli K-12 NMHK8 strain was left at room temperature for 23 days before it was observed by SEM at different magnifications. (A) In this drying biosaline pattern, the loss of the $\mathrm{NaCl}+$ bacterial cells cover revealed the underlying bacterial pattern situated below that acts as a scaffold that supports the formation of the biosaline $\mathrm{NaCl}+$ bacteria drying pattern. (B) Enlargement of the box in (A). (C) Enlargement of the box in (B). The individual bacterial cells are clearly visualized in this image and are marked with tiny white arrows. The open white arrows indicate the bulk of the pattern formed by tightly packed bacterial cells, whereas the white arrowheads indicate the residual cover of $\mathrm{NaCl}+$ bacteria. (D-O) A dried biosaline biofilm of E. coli W3110 was left at room temperature for 70 days before it was observed with SEM at different magnifications. In $(\mathrm{N})$ and $(\mathrm{O})$, the arrowheads show the filmlike thin layer of the drying biosaline pattern that is clearly visualized. Secondary electrons were used to capture images (A, B, C, D, G, I, J, M, N, O), whereas images (E, F, H, K, L) were taken with backscattered electrons. 


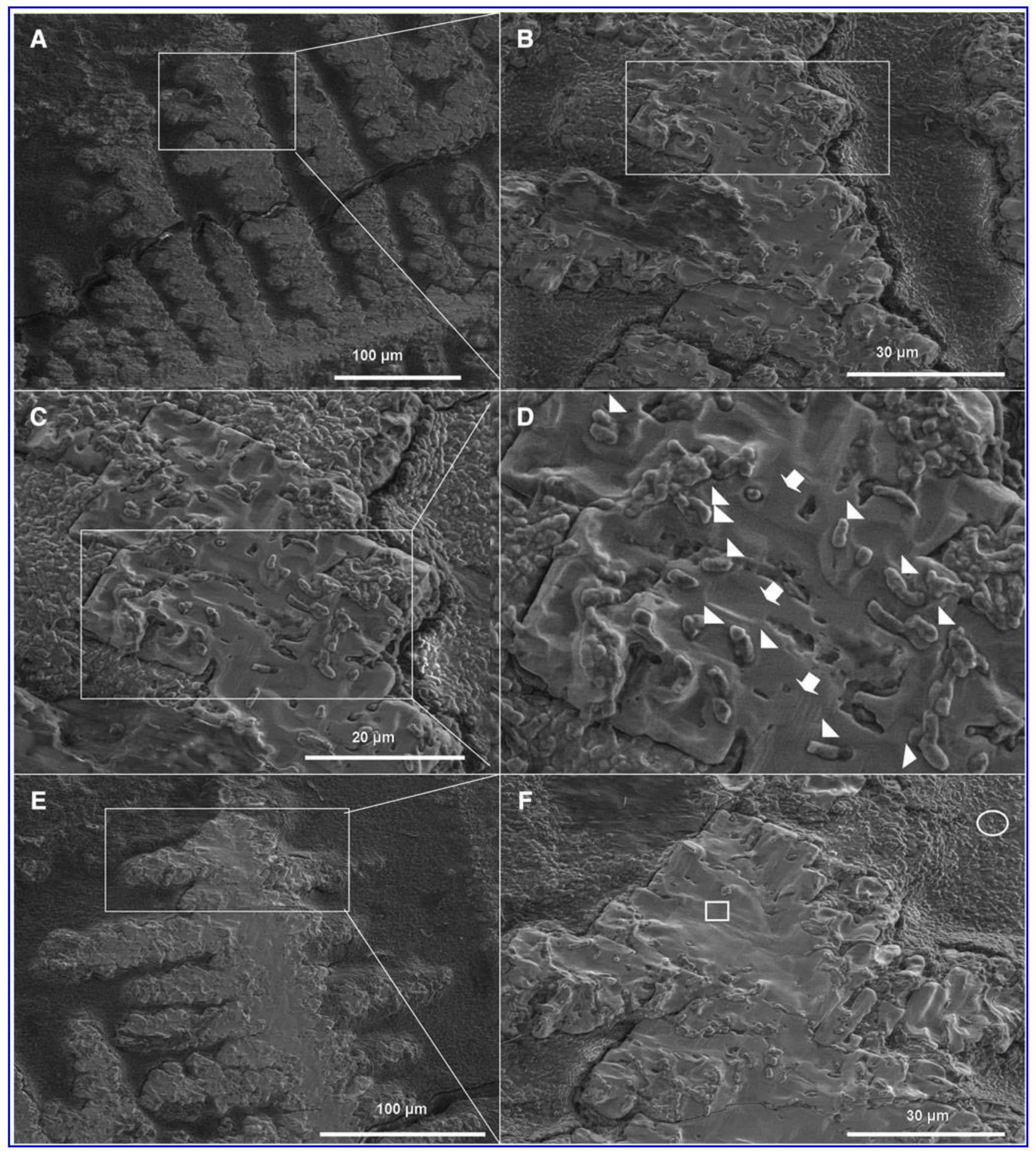

FIG. 5. Scanning electron microscope images showing the appearance of a film layer with a fern-leaf morphology containing mineralized cells, and EDS analysis of relevant regions in this pattern. (A-F) Zoomed views of a typical 70-dayold thin film of E. coli K-12 W3110 strain, showing a layered fernlike morphology. (C) Enlarged view of the box region in (B). (D) The arrowheads indicate "mineralized" cells conjugated with $\mathrm{NaCl}$ (arrows) that form a coat or crust over the underlying bacterial pattern. (G) Typical EDS spectrum obtained in the open square box in (F). (H) Typical EDS spectrum obtained in the region shown by an open circle in $(\mathrm{F})$. (Color graphics for $\mathrm{G}$ and $\mathrm{H}$ [next page] are available online at www.liebertonline.com/ast.) 


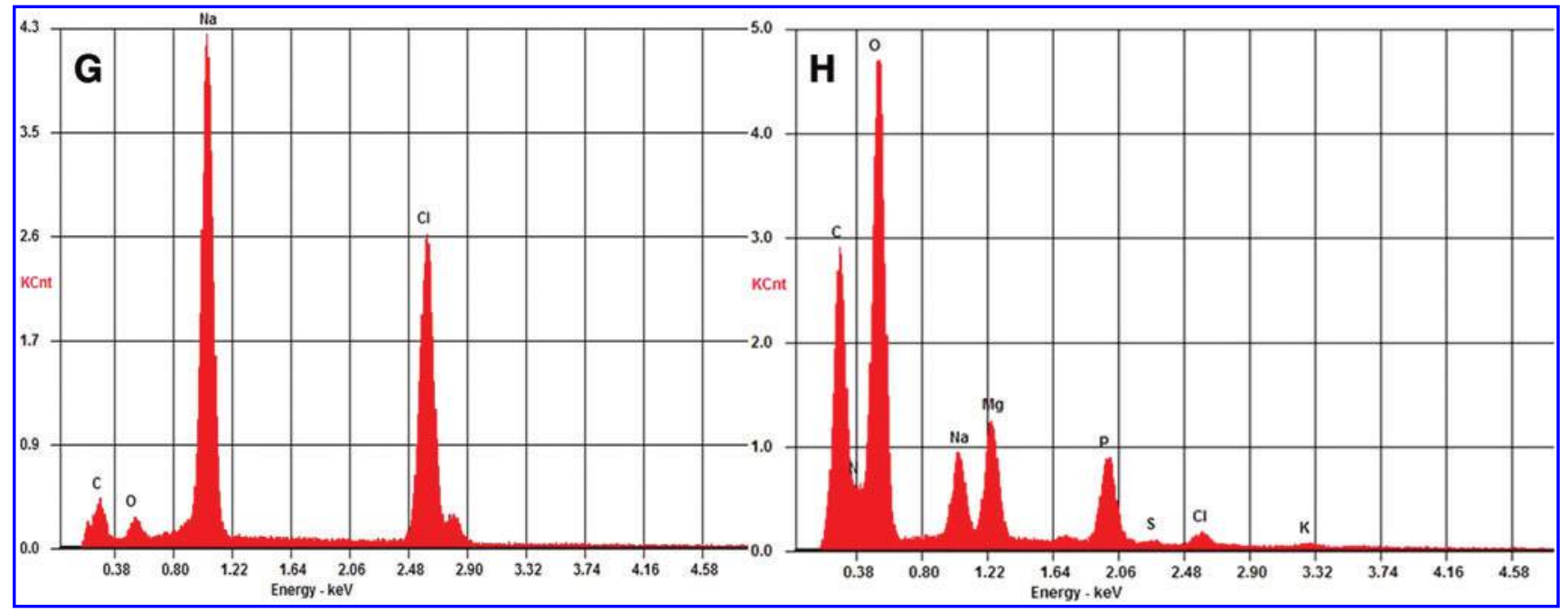

FIG. 5. (Continued).

\section{Discussion}

The findings presented in this work have several important astrobiological implications, which we address below.

\subsection{Relevance for understanding bacterial anhydrobiosis}

Escherichia coli bacteria employ similar mechanisms as those other bacteria employ to resist osmotic shock caused by increased water salinity in aquatic environments. For example, high water salinity prompts $E$. coli to synthesize trehalose and sucrose, uptake environmental glycine betaine, and produce EPS (Billi et al., 2000). Nevertheless, the mechanisms that E. coli employs to achieve resistance to extreme desiccation are poorly understood. From an astrobiological point of view, a relevant result of our study is that E. coli bacterial cells inside the biosaline patterns displayed vital reanimation upon rehydration (Fig. 6A-6M and 6P). Apparently, the patterns are completely desiccated structures with a water content below the level considered as the truly anhydrobiotic desiccated state; that is, the bacterial cells inside these structures can, as in toto entities, enter into a quiescent anhydrobiotic state while participating in the formation of these complex biosaline patterns.

In marked contrast, for instance, to air-dried bacterial cells, the cells in these patterns have a $\mathrm{NaCl}$ covering, can intermingle with this $\mathrm{NaCl}$, and establish a strong interaction with this salt. Thus, we consider that this represents a new mode of drying, most likely with this saline coating shell providing protection against other environmental stressors such as cold, acids, antibiotics, UV radiation, and so on. Interestingly, it was previously reported that vegetative chemolithoautotrophic bacterial cells covered with very thin layers of a Mars analog regolith showed a higher survivability to UV radiation than bacterial cells that lack the protection provided by these covering layers (Gómez et al., 2010). Future experiments must clarify this suggestion.

\subsection{Biomineralogical implications: how do the biosaline bacterial drying patterns form?}

Biomineralization is the process by which living organisms produce minerals. Biologically induced mineralization
(BIM) and biologically controlled mineralization (BCM) are two bacterially mediated modes that form minerals depending on the level of control the organism has over this mineral-formation process (Lowenstam, 1981; Lowenstam and Weiner, 1989; Mann, 2001). Because minerals produced under biological control have distinctive crystallographies, morphologies, and isotopic ratios that distinguish them from abiotically produced minerals with the same chemical composition (and are stable through geological time), the use of minerals that are the result of BCM processes as biomarkers (indications of past life) has been proposed for extraterrestrial life and could play an important role in the search for past or present life on Mars (Banfield et al., 2001; Blanco et al., 2006).

Several mechanisms have been proposed for modulating biomineralization by bacteria (BIM). These include metabolic processes that alter $\mathrm{pH}$ and supersaturation, as well as cell surface properties of EPS, cell membrane, and S-layers that may alter mineral nucleation. In BCM, organic compoundsproteins, lipids, proteoglycans, and polysaccharides - are known to control the structure, composition, shape, and organization of inorganic crystals (Mann, 2001).

Despite the study of drying patterns in evaporating droplets in abiotic systems, many aspects of how this pattern is actually formed are not yet fully understood. Are the drying biosaline bacterial patterns products of a genuine BIM formative process? A previous study conducted by Shiba et al. (2003) reported the formation of dendritic architectures in evaporating $\mathrm{NaCl}$ droplets containing the protein 288 (a synthetic periodic polypeptide). Although these authors were able to identify that the dendritic structures were constructed with $\mathrm{NaCl}$, they were not able to clarify whether these structures contained the 288 proteins as well. Our studies with SEM, EDS analysis and video movies of the $E$. coli biosaline drying pattern formation show that these patterns have a layered organization, with the bacterial cells entering as whole entities (maintaining their cellular integrity) to form the drying pattern. Thus, not only bio-macromolecules, but also bacterial cells, as whole entities, can form drying biosaline patterns.

Given that proteins such as 288 can modulate the macroscopic habit exhibited by $\mathrm{NaCl}$, it is tempting to speculate 


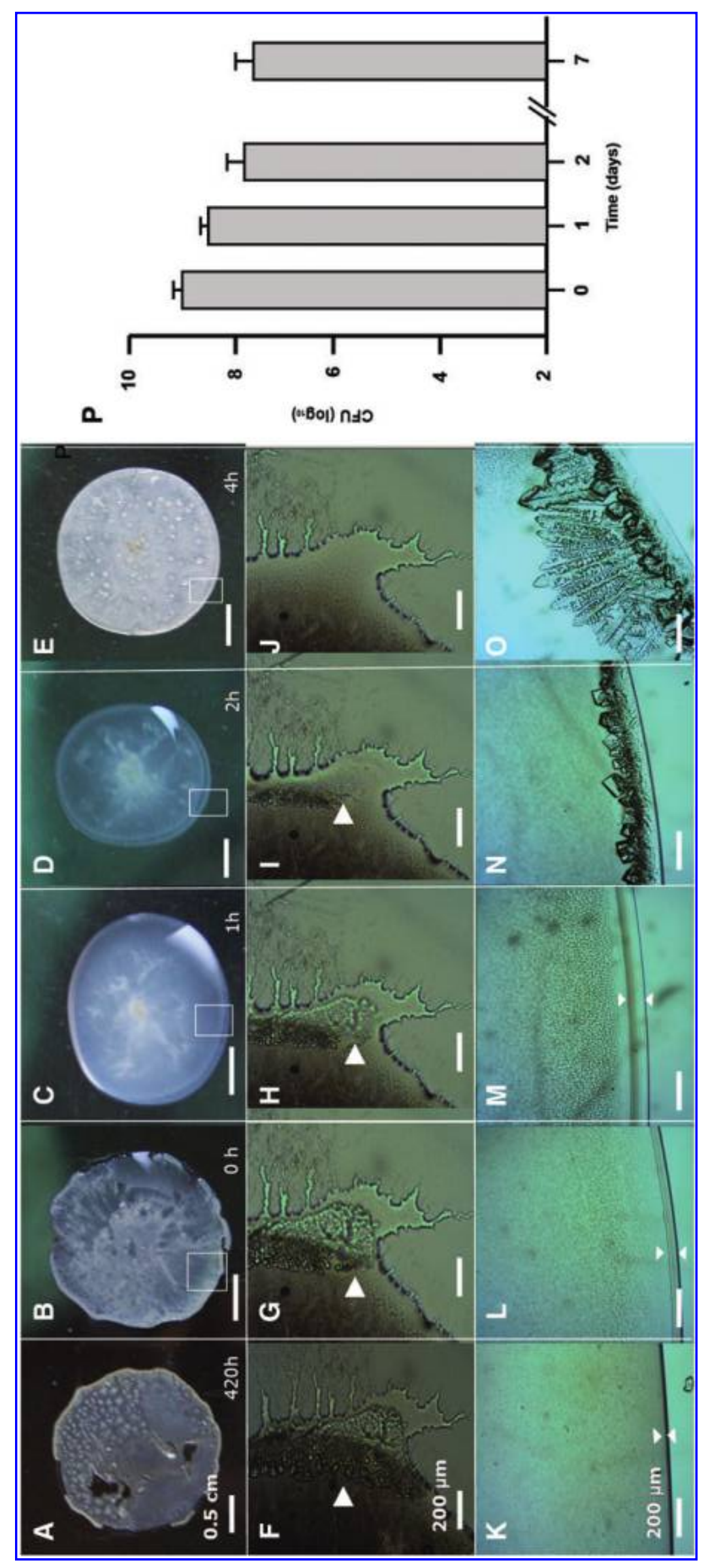

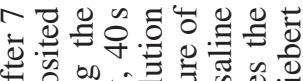

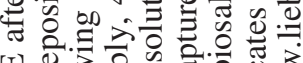

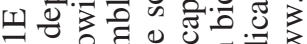

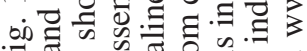

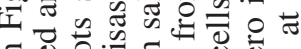

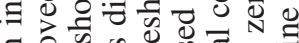

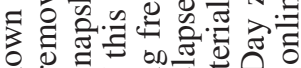
ए ए ๒

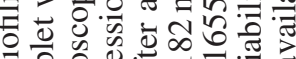

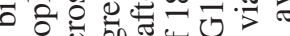

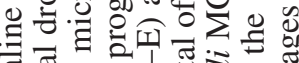

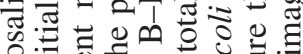

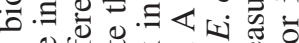

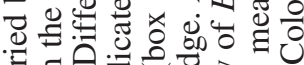

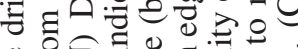

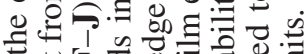

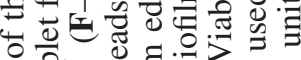

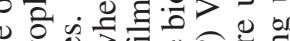

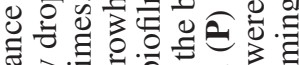
㐘:

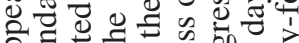

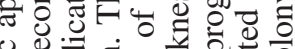

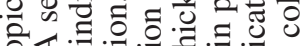

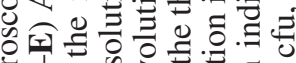

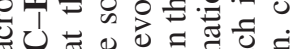
$\sum$ ㄴ. 文.

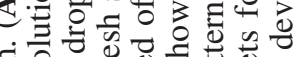

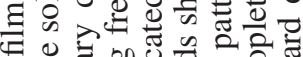

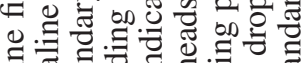
芯 可

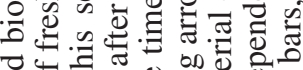

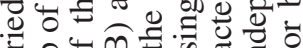

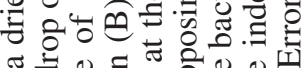
ส फ

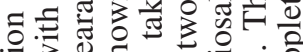

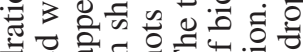

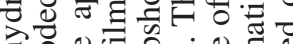

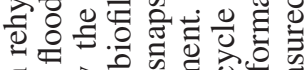

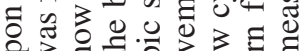

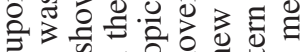

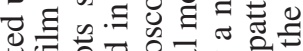

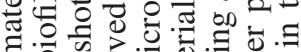

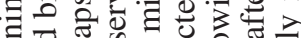

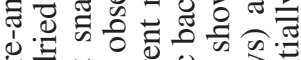
U士

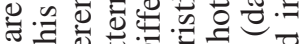

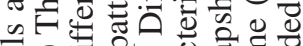

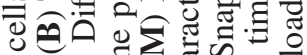

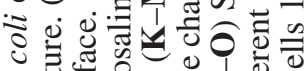

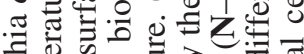

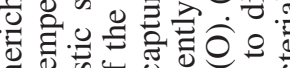
ป Ф 므뉴 I ๑ 记交 
that modulation observed in drying biosaline patterns of E. coli cells could be caused by a protein component (or components) present in the bacterial surface or even a protein secreted by the bacteria to the surrounding medium (during the phase of adaptation on the evaporating droplet) that acts as a template-scaffold and promotes and organizes the $\mathrm{NaCl}$ deposition. However, the possibility that other components distinct from the proteins produced by $E$. coli (e.g., EPS exopolysaccharides) could be involved in this process cannot be discounted. Therefore, we assume that the assembly of $\mathrm{NaCl}$ and bacterial cells into dendrites of various shapes is controlled by the use of bacterial assembled structures as templates that ultimately incorporate the entire cell into the self-assembly. In view of this, we suggest that the drying bacterial pattern formations could be considered as a kind of BIM process (Frankel and Bazylinski, 2003). Therefore, the formation of bacterial saline drying patterns represents an excellent mode for studying the mechanisms that underlie bacterially induced biomineralization and could have a relevant role in understanding the process of "biologically induced" or "organic matrix-mediated" BIM.

\subsection{Biological implications and future research}

Finally, what are the biological implications of these results? Could $E$. coli use these biosaline drying formations as a survival strategy in response to different stressful situations? It is tempting to speculate that indeed their formation could be used by bacteria as a "collective last resort" against extreme environmental situations for achieving biological survival. The phenomenon is "collective" because the bacterial cells inside these biosaline formations could be effectively sequestered and protected in drying situations to endure, in this manner, these extreme environmental conditions; thus this may represent an optimal strategy for survival. The cells can achieve a complete dormancy in this anhydrobiotic state, as they are protected with a saline coat. They would furthermore be refractory to any kind of environmental assaults that normally require wet conditions and of living metabolic activity that could result in damage to key cellular components (Gómez-Gómez, 2010). Therefore, the study of these kinds of biosaline dying patterns will help reveal the biological mechanisms employed by bacteria for survival in extreme dry environmental conditions.

Several kinds of pattern formations have been described in colonies of $E$. coli under different environmental and nutritional conditions (Budrene and Berg, 1991; Darton, 2010; Zorzano et al., 2005). However, despite intensive research in recent years, many aspects of $E$. coli pattern formation, as well as how the morphology of the patterns change when they are exposed to different stresses (e.g., osmotic, antibiotic, oxidative, etc.), are poorly understood. In this regard, due to the availability of their complete genomic sequence (Blattner et al, 1997), the comprehensive set of single-gene knockout mutants (Baba et al., 2006), as well as their rapid growth and easy genetic manipulation, E. coli constitutes the reference model for studying the molecular, physiological, and genetic basis that underlies the biosaline drying pattern formation in biological systems. Furthermore, the bacterial biosaline drying structures could be an appropriate vehicle for bacterial dispersal. Future experiments must clarify these fundamental issues. Inter- estingly, in this regard, it is has been suggested that the search for extraterrestrial life should target chloride-bearing salts, for example, halite found on Mars, particularly in layered crystalline salts with preserved growth textures and fine-scale layering (Osterloo et al., 2008). Our discovery that bacteria can participate in the formation of bio- $\mathrm{NaCl}$ saline layered patterns makes the study of these bioformations of unmistakable astrobiological interest.

\section{Conclusions}

Using sessile saline droplets containing E. coli cells in this work, we report the discovery that water evaporation drives a salt-induced coupled self-assembly of bacterial cells with $\mathrm{NaCl}$ salt into biosaline quiescent drying complex patterns. Thus, most interestingly, the bacterial cells as whole, and under certain environmental conditions, can undergo a controlled self-organization into spatial formations in which the bacterial cells inside these patterns are capable of vital reanimation. Moreover, we judge that these findings will have important implications for understanding the capacity of bacteria to resist and survive extreme conditions. Such stressful environments can be encountered, for example, in the harsh environmental conditions in outer space or in numerous astrobiological sites where the search for life will take place in the coming decades, as well as in the many dry ecological niches on Earth.

\section{Acknowledgments}

The authors express their gratitude to Illias Tagkopoulos, Paul S. Cohen, Patrick C. Cirino, Sine L. Svenningsen, and to Gisela Storz for kindly providing them with the $E$. coli K-12 MG1655, MG1655 str $^{\mathrm{R}}$, W3110, NMHK8B, NM525 and GSO553 derivate strains, respectively, used in this work. We also thank an anonymous reviewer for constructive comments that have improved the quality of the manuscript.

\section{Disclosure Statement for All the Authors}

The authors declare that they have no competing interests.

\section{Abbreviations}

ABE, Agar Bacteriológico Europeo; BCM, biologically controlled mineralization; BIM, biologically induced mineralization; EDS, energy dispersive X-ray spectrometry; EPS, extracellular polymeric substances; LB, Luria-Bertani; SEM, scanning electron microscopy.

\section{References}

Baba, T., Ara, T., Hasegawa, M., Takai, Y., Okumura, Y., Baba, M., Datsenko, K.A., Tomita, M., Wanner, B.L., and Mori, H. (2006) Construction of Escherichia coli K-12 in-frame, single-gene knockout mutants: the Keio collection. Mol Syst Biol 2, doi:10.1038/msb4100050.

Ball, P. (1999) The Self-Made Tapestry-Pattern Formation in Nature, Oxford University Press, Oxford, UK.

Banfield, J.F., Moreu, J.W., Chan, C.S., Welch, S.A., and Little, B. (2001) Mineralogical biosignatures and the search for life on Mars. Astrobiology 1:447-465.

Billi, D. and Potts, M. (2000) Life without water: responses of prokaryotes to desiccation. In Environmental Stressors and 
Gene Responses, edited by K.B. Storey and J.M. Storey, Elsevier, Amsterdam, pp 181-192.

Billi, D. and Potts, M. (2002) Life and death of dried prokaryotes. Res Microbiol 153:7-12.

Billi, D., Wright, D.J., Helm, R.F., Prickett, T., Potts, M., and Crowe, J.H. (2000) Engineering desiccation tolerance in Escherichia coli. Appl Environ Microbiol 66:1680-1684.

Blanco, A., D'Elia, M., Licchelli, D., Orofino, V., and Fonti, S. (2006) Studies of biominerals relevant to the search for life on Mars. Orig Life Evol Biosph 36:621-622.

Blattner, F.R., Plunkett, G., III, Bloch, C.A., Perna, N.T., Burland, V., Riley, M., Collado-Vides, J., Glasner, J.D., Rode, C.K., Mayhew, G.F., Gregor, J., Davis, N.W., Kirkpatrick, H.A., Goeden, M.A., Rose, D.R., Mau, B., and Shao, Y. (1997) The complete genome sequence of Escherichia coli K-12. Science 277:1453-1462.

Brutin, D., Sobac, B., Loquet, B., and Sampol, J. (2011) Pattern formation in drying drops of blood. J Fluid Mech 667:85-95.

Budrene, E.O. and Berg, H.C. (1991) Complex patterns formed by motile cells of Escherichia coli. Nature 349:630-633.

Camazine, S., Deneubourg, J.-L., Franks, N.R., Sneyd, J., Theraula, G., and Bonabeau, E. (2001) What is self-organization? In Self-Organization in Biological Systems, edited by S. Camazine, J.-L. Deneubourg, N.R. Franks, J. Sneyd, G. Theraulaz, and E. Bonabeau, Princeton University Press, Princeton, NJ, pp 7-14.

Carr, M. (2006) The Surface of Mars, Cambridge University Press, Cambridge, UK.

Chen, G. and Mohamed, G.J. (2010) Complex protein patterns formation via salt-induced self-assembly and droplet evaporation. Eur Phys J E Soft Matter 33:19-26.

Copeland, M.F. and Weibel, D.B. (2009) Bacterial swarming: a model system for studying dynamic self-assembly. Soft Matter 5:1174-1187.

Darton, N.C. (2010) Structure and pattern in bacterial colonies. In Experimental and Computational Techniques in Soft Condensed Matter Physics, edited by J. Olafsen, Cambridge University Press, Cambridge, UK, pp 279-325.

De Duve, C. (1996) Vital Dust: Life as a Cosmic Imperative, BasisBook, New York.

Deegan, R.D. (2000) Pattern formation in drying drops. Phys Rev E Stat Nonlin Soft Matter Phys 61:475-485.

Dragosits, M., Mozhayskiy, V., Quinones-Soto, S., Park, J., and Tagkopoulos, I. (2013) Evolutionary potential, cross-stress behavior and the genetic basis of acquired stress resistance in Escherichia coli. Mol Syst Biol 9, doi:10.1038/msb.2012.76.

Frankel, R.B. and Bazylinski, D.A. (2003) Biologically induced mineralization by bacteria. In Biomineralization, Reviews in Mineralogy and Geochemistry Vol. 54, edited by P.M. Dove, J.J. De Yoreo, and S. Weiner, Mineralogical Society of America and Geochemical Society, Washington, DC, pp 95114.

Gauger, E.J., Leatham, M.P., Mercado-Lubo, R., Laux, D.C., Conway, T., and Cohen, P.S. (2007) Role of motility and the fhDC operon in Escherichia coli MG1655 colonization of the mouse intestine. Infect Immun 75:3315-3324.

Gómez, F., Mateo-Martí, E., Prieto-Ballesteros, O., MartínGago, J., and Amils, R. (2010) Protection of chemolithoautotrophic bacteria exposed to simulated Mars environmental conditions. Icarus 209:482-487.

Gómez-Gómez, J.M. (2010) Aging in bacteria, immortality or not-a critical review. Curr Aging Sci 3:198-218.

Gómez-Gómez, J.M. and Amils, R. (2014) Crowning: a novel Escherichia coli colonizing behaviour generating a self- organized corona. BMC Res Notes 7, doi:10.1186/1756-05007-108.

Gómez-Gómez, J.M., Baquero, F., and Blazquez, J. (1996) Cyclic AMP receptor protein positively controls gyrA transcription and alters DNA topology after nutritional upshift in Escherichia coli. J Bacteriol 178:3331-3334.

Gómez-Gómez, J.M., Manfredi, C., Alonso, J.C., and Blázquez, J. (2007) A novel role for RecA under non-stress: promotion of swarming motility in Escherichia coli K-12. BMC Biol 5, doi:10.1186/1741-7007-5-14.

Grant, W.D. (2004) Life at low water activity. Philos Trans $R$ Soc Lond B Biol Sci 359:1249-1266.

Harshey, R.M. (1994) Bees aren't the only ones: swarming in Gram-negative bacteria. Mol Microbiol 13:389-394.

Høyland-Kroghsbo, N.M., Mærkedahl, R.B., and Svenningsen, S.L. (2013) A quorum-sensing-induced bacteriophage defense mechanism. mBio 4, doi:10.1128/mBio.00362-12.

Jing, J., Reed, J., Huang, J., Hu, X., Clarke, V., Edington, J., Housman, D., Anantharaman, T.S., Huff, E.J., Mishra, B., Porter, B., Shenker, A., Wolfson, E., Hiort, C., Kantor, R., Aston, C., and Schwartz, D.C. (1998) Automated high resolution optical mapping using arrayed, fluid-fixed DNA molecules. Proc Natl Acad Sci USA 95:8046-8051.

Jönsson, K.I. (2007) Tardigrades as a potential model organism in space research Astrobiology 7:757-766.

Kaya, D., Belyi, V.A., and Muthukumar, M. (2010) Pattern formation in drying droplets of polyelectrolyte and salt. J Chem Phys 133, doi:10.1063/1.3493687.

Kearns, D.B. (2010) A field guide to bacterial swarming motility. Nat Rev Microbiol 8:634-644.

Kennedy, M.J., Reader, S.L., and Swierczynski, L.M. (1994) Preservation records of micro-organisms: evidence of the tenacity of life. Microbiology 140:2513-2529.

Khankal, R, Chin, J.W., Ghosh, D., and Cirino, P.C. (2009) Transcriptional effects of CRP* expression in Escherichia coli. J Biol Eng 3, doi:10.1186/1754-1611-3-13.

Kurihara, S., Suzuki, H., Oshida, M., and Benno, Y. (2011) A novel putrescine importer required for type 1 pili-driven surface motility induced by extracellular putrescine in Escherichia coli K-12. J Biol Chem 286:10185-10192.

Lowenstam, H.A. (1981) Minerals formed by organisms. Science 211:1126-1131.

Lowenstam, H.A. and Weiner, S. (1989) On Biomineralization, Oxford University Press, New York.

Ma, L., Liu, H., Zhu, Z., Wang, H., Xu, X., Na, N., and Ouyang, J. (2013) A controlled self-assembly of CdTe quantum dots into different microscale dendrite structures by using proteins as templates. J Mater Chem A Mater Energy Sustain 1: 15082-15088.

Mann, S. (2001) Biomineralization: Principles and Concepts in Bioinorganic Materials Chemistry, Oxford University Press, Oxford, UK.

McKay, C.P. (2004) What is life-and how do we search for it in other worlds? PLoS Biol 2, doi:10.1371/journal.pbio.0020302.

Okubo, T. (2011) Dissipative crystallization of aqueous mixtures of potassium salts of poly(riboadenylic acid) and poly (ribouridylic acid). Colloids Surf B Biointerfaces 87:439-446.

Okubo, T., Mizutani, M., Takahashi, S., and Tsuchida, A. (2010) Dissipative crystallization of sodium salt of deoxyribonucleic acid. Colloid Polym Sci 288:1435-1444.

Osterloo, M.M., Hamilton, V.E., Bandfield, J.L., Glotch, T.D., Baldridge, A.M., Christensen, P.R., Tornabene, L.L., and Anderson, F.S. (2008) Chloride-bearing materials in the southern highlands of Mars. Science 319:1651-1654. 
Potts, M. (1994) Desiccation tolerance of prokaryotes. Microbiol Rev 58:755-805.

Shiba, K., Honma, T., Minamisawa, T., Nishiguchi, K., and Noda, T. (2003) Distinct macroscopic structures developed from solutions of chemical compounds and periodic proteins. EMBO Rep 4:148-153.

Staley, J.T., Gunsalus, R.P., Lory, S., and Perry, J.J. (2007) Microbial Life, Sinauer, Sunderland, MA.

Thomason, M.K., Fontaine, F., De Lay, N., and Storz, G. (2012) A small RNA that regulates motility and biofilm formation in response to changes in nutrient availability in Escherichia coli. Mol Microbiol 84:17-35.

Vítek, P., Jehlička, J., Edwards, H.G., Hutchinson, I., Ascaso, C., and Wierzchos, J. (2012) The miniaturized Raman system and detection of traces of life in halite from the Atacama Desert: some considerations for the search for life signatures on Mars. Astrobiology 12:1095-1099.

Westall, F., Loizeau, D., Foucher, F., Bost, N., Betrand, M., Vago, J., and Kminek, G. (2013). Habitability on Mars from a microbial point of view. Astrobiology 13:887-897.

Zhang, Q. and Yan, T. (2012) Correlation of intracellular trehalose concentration with desiccation resistance of soil Escherichia coli populations. Appl Environ Microbiol 78: 7407-7413.

Ziolkowski, L.A., Wierzchos, J., Davila, A.F., and Slater, G.F. (2013) Radiocarbon evidence of active endolithic microbial communities in the hyperarid core of the Atacama Desert. Astrobiology 13:607-616.

Zorzano, M-P., Cuevas, M-T., Hochberg, D., and GómezGómez, J-M. (2005) Reaction-diffusion model for pattern formation in E. coli swarming colonies with slime. Phys Rev E Stat Nonlin Soft Matter Phys 71, doi:10.1103/PhysRevE .71 .031908 .

Address correspondence to:

José María Gómez Gómez Laboratory of BioMineralogy and Astrobiological Research (LBMARS) Unidad Asociada UVA-CSIC Edificio INDITI Av. Francisco Valles 8 Parque Tecnologico de Boecillo Parcela 203 E-47151 Boecillo, Valladolid Spain

E-mail: jmgomezseg@gmail.com

Submitted 29 January 2014 Accepted 27 April 2014 